

\section{LEGAL NOTICE}

This report was prepared as an account of Government sponsored work. Neither the United States nor the Commission, nor any person acting on behalf of the Commission:

A. Makes any warranty or representation expressed or implied, with respect to the accuracy, completeness, or usefulness of the information contained in this report, or that the use of any information, apparatus, method, or prosess disclosed in this report may not infring• privately owned rights; or

B. Assumes any liabilities with respect to the use of, or for damages resulting from the use of any information, apparatus, method, or process disclosed in this report.

As used in the above, "person acting on behalf of the commission" includes any employee or contractor of the Commission, or employee of such contractor, to the extent that such employee or contractor of the Commission, or employee of such contractor prepares disseminates, or provides access to, any information pursuant to his employment or contract with the Commission, or his employment with such contractor. 


\section{DISCLAIMER}

This report was prepared as an account of work sponsored by an agency of the United States Government. Neither the United States Government nor any agency Thereof, nor any of their employees, makes any warranty, express or implied, or assumes any legal liability or responsibility for the accuracy, completeness, or usefulness of any information, apparatus, product, or process disclosed, or represents that its use would not infringe privately owned rights. Reference herein to any specific commercial product, process, or service by trade name, trademark, manufacturer, or otherwise does not necessarily constitute or imply its endorsement, recommendation, or favoring by the United States Government or any agency thereof. The views and opinions of authors expressed herein do not necessarily state or reflect those of the United States Government or any agency thereof. 


\section{DISCLAIMER}

Portions of this document may be illegible in electronic image products. Images are produced from the best available original document. 


\title{
DEVELOPMENT OF THE UNDER-SODIUM
}

\author{
ULTRASONIC SCANNER
}

\author{
United States Atomic Energy Commission \\ AEC Contract No. AT(11-1)-865 \\ Project Agreement No. 14
}

C. C. Scott

L. R. Kovac

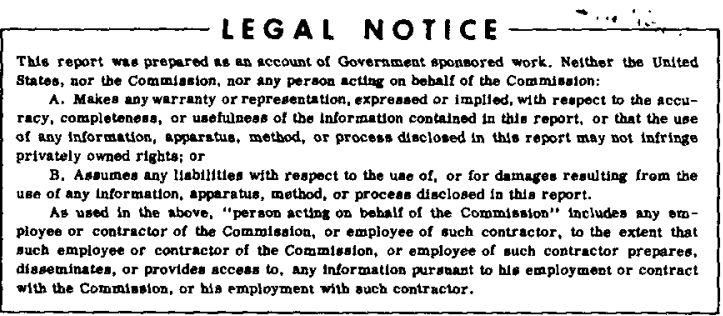

\footnotetext{
Approved Cbyde C Acoll

C. C. Scott

Project Engineer

APDA
} 
TABLE OF CONTENTS

$\underline{\text { Page }}$

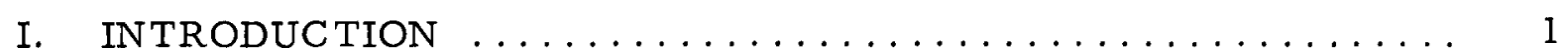

II. FEASIBILITY STUDIES FOR AN ACOUSTIC IMAGE CONVERSION SYSTEM $\ldots \ldots \ldots \ldots \ldots \ldots \ldots \ldots \ldots \ldots \ldots \ldots \ldots$

III. PROGRAM FOR THE DESIGN AND DEMONSTRATION OF A PROTOTYPE UNDER-SODIUM ULTRASONIC SCANNER $\ldots \ldots .5$

IV. BONDING INVESTIGATIONS FOR ACOUSTIC TRANSDUCERS $\ldots 7$. 7

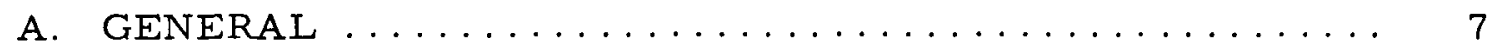

B. EXPERIMENTAL PROCEDURES AND RESULTS . . . . . . . . 7

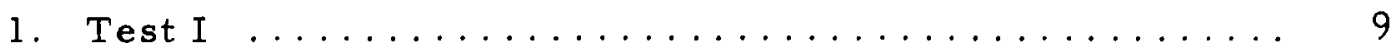

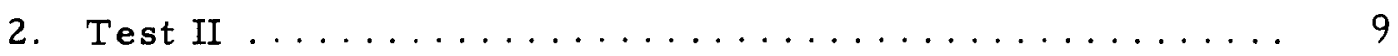

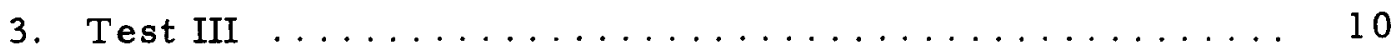

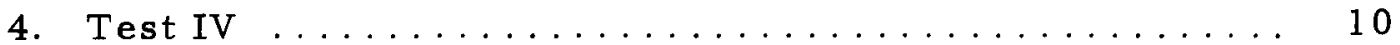

5. Conclusions ...................... 10

V. ACOUSTIC ATTENUATION AS A FUNCTION OF IMPURITIES IN SODIUM $\ldots \ldots \ldots \ldots \ldots \ldots \ldots \ldots \ldots \ldots \ldots$ 


\section{INTRODUCTION}

This report is an addendum to APDA-210, "Development of the Under-Sodium Ultrasonic Scanner". The previous report covered the feasibility studies that preceded development of the single narrow-beam transducer scanning system, as well as the developmental work for that system. This addendum presents knowledge gained in the program subsequent to the issuance of that report. Areas discussed include the following: feasibility studies for the acoustic image conversion system; program for the design and demonstration of a prototype under-sodium ultrasonic scanner; bonding studies for acoustic transducers; and acoustic attenuation as a function of impurities in sodium. 
$\bullet$ 


\section{FEASIBILITY STUDIES FOR AN ACOUSTIC IMAGE CONVERSION SYSTEM}

A study was conducted in FY-1968 to determine the feasibility of producing images of objects with an acoustic image conversion system. Scanning with such a system differs from a $\mathrm{C}$-scan mode of scanning in that the acoustic image conversion tube remains stationary and the images are obtained by electronically scanning the back faces of piezoelectric disks.

The overall scope of the study was to determine the following:

- The feasibility of operating piezoelectric materials for image scanning at temperatures to $600 \mathrm{~F}$.

- The feasibility of transceiving in the pulse-echo mode.

- The feasibility of operating electronic components such as electron guns and electron multipliers at temperatures to $600 \mathrm{~F}$.

Experiments were conducted in an oven at temperatures to $350 \mathrm{~F}$, in water at temperatures to approximately $200 \mathrm{~F}$, and in a silicone fluid at temperatures to $425 \mathrm{~F}$. The results of the experiments indicated that acoustic image conversion systems can be designed and fabricated that will perform satisfactorily at temperatures to $600 \mathrm{~F}$. In addition, data were developed that can be used to predict the piezoelectric properties of materials at elevated temperatures.

The details of the study are reported in APDA-223. 
•. 


\section{PROGRAM FOR THE DESIGN AND DEMONSTRATION OF A PROTOTYPE UNDER-SODIUM ULTRASONIC SCANNER}

A program for the design, procurement, and testing was developed to demonstrate the feasibility and desirability of applying the single narrowbeam transducer scanner to large sodium-cooled reactors for a variety of purposes. The program is based on the ultrasonic transducers that have been developed and tested for the AEC by APDA and on the current stateof-the-art of under-sodium mechanism design. The principal tasks that would constitute the demonstration are the following:

- The preparation of conceptual systems' descriptions of a reactorscale prototype of an under-sodium ultrasonic scanner and of a suitable test rig for demonstrating the scanner.

- The preparation of complete drawings and specifications for the fabrication, assembly, erection, and maintenance of the scanner prototype and the test rig.

- The preparation of detailed specifications for demonstration tests of selected typical reactor applications of the under-sodium scanner.

- The procurement and erection of the test rig in a suitable enclosure adjacent to an existing sodium loop facility that would service the demonstration test rig.

- The procurement and installation of the scanner prototype and its related equipment.

- The performance of suitable acceptance and preoperational tests of the test rig and the scanner prototype.

- The performance of demonstration tests of selected applications.

- The evaluation of the results and the significance of the demonstration tests.

- The preparation of a topical report on the demonstration and its findings, with recommendations for future applications and further development. 
The applications that were proposed for demonstration are listed here and defined briefly.

- Obstruction detector (sweep). Search for any subassemblies that are projecting above their normal positions in the reactor.

- Fuel-handler calibration. Measure distances between the transducer (positioned at the fuel-handling gripper) and benchmark targets to obtain the gripper's location by triangulation. (The use of corner targets for benchmarks permits the "seeing" of targets from any direction.)

- Subassembly identification. Read an identification mark engraved into the upper end of each fuel subassembly.

- Subassembly orientation. Read an orientation mark engraved into the upper end of each fuel subassembly. (The identification marks, however, may give sufficient orientation information.)

- Migratory-plug locator. Search reactor plenums or flow channels to detect, locate, and identify foreign objects that could cause flow blockage.

- Search and retrieval. Search for lost objects or components and provide guidance during retrieval.

- Support-plate inspection. Inspect fuel subassembly support plates for warpage by measuring offset distances from a reference plane, and inspect for cavitation damage at seal surfaces by examining for pitting.

- Dimensional inspection. Inspect for dimensional changes occuring to in-reactor components by utilizing plate-thickness measurements, relative location measurements, or bow or warpage measurements on originally flat surfaces.

The details of the proposed program are reported in APDA-220. 


\section{BONDING INVESTIGATIONS FOR ACOUSTIC TRANSDUCERS}

\section{A. GENERAL}

Based on acoustical requirements, the optimum design for a ceramic transducer with a backing layer and metal lens would be for the three components to be an integrally bonded unit, as shown in Figure 1. This assembly would require a ceramic-to-metal brazed joint between the backing layer and the transducer and between the transducer and the metal lens.

In regard to brazed ceramic metal composites, the ideal condition would exist if, in the finished assembly, the thermal expansion coefficients of the ceramic, the brazing material, and the metal were alike. This would result in the absolute minimum of residual and service thermal stresses. From a practical viewpoint, this condition is almost impossible to realize. However, to minimize stresses, particularly tensile stresses in the ceramic component, the combination of suitable materials should be such that there is as small a difference in their thermal expansion coefficients as possible. In addition, the ceramic component should be subjected to only compressive residual or service stresses. To produce these results, the braze filler material, in addition to having satisfactory wetting properties of both the metal and ceramic, should have a thermal expansion coefficient greater than that of the ceramic so that in the brazing operation only compressive residual stresses are produced in the ceramic.

The maximum service temperature of $600 \mathrm{~F}$ and the allowable maximum exposure temperature of $1200 \mathrm{~F}$ for the transducer disk limited the choice of possible brazing metals. As described in the following paragraphs, various approaches using different brazing materials were attempted to produce a lens-piezoelectric disk-backing assembly.

\section{B. EXPERIMENTAL PROCEDURES AND RESULTS}

The ceramic transducer disks used in the experiments were made of lead zirconate-titanate (PZT-5), manufactured by the Piezoelectric Division of the Clevite Corporation. The ceramic disks had a composition of approximately equimolar proportions of $\mathrm{PbO}, \mathrm{ZrO}_{2}$, and $\mathrm{TiO}_{2}$. The disks were 1 inch in diameter and 0.035-inch thick, and their flat faces were coated with silver. The dummy lenses, made from Monel alloy, were 2 inches in diameter and 0.075 -inch thick, and their faces were ground flat to within 0.0002 inch and further lapped to a surface finish finer than 4 microinch RMS. The backings, made from copper, were 1 inch in diameter and 1 -inch thick, and their faces were ground flat to within 0.0002 inch. 


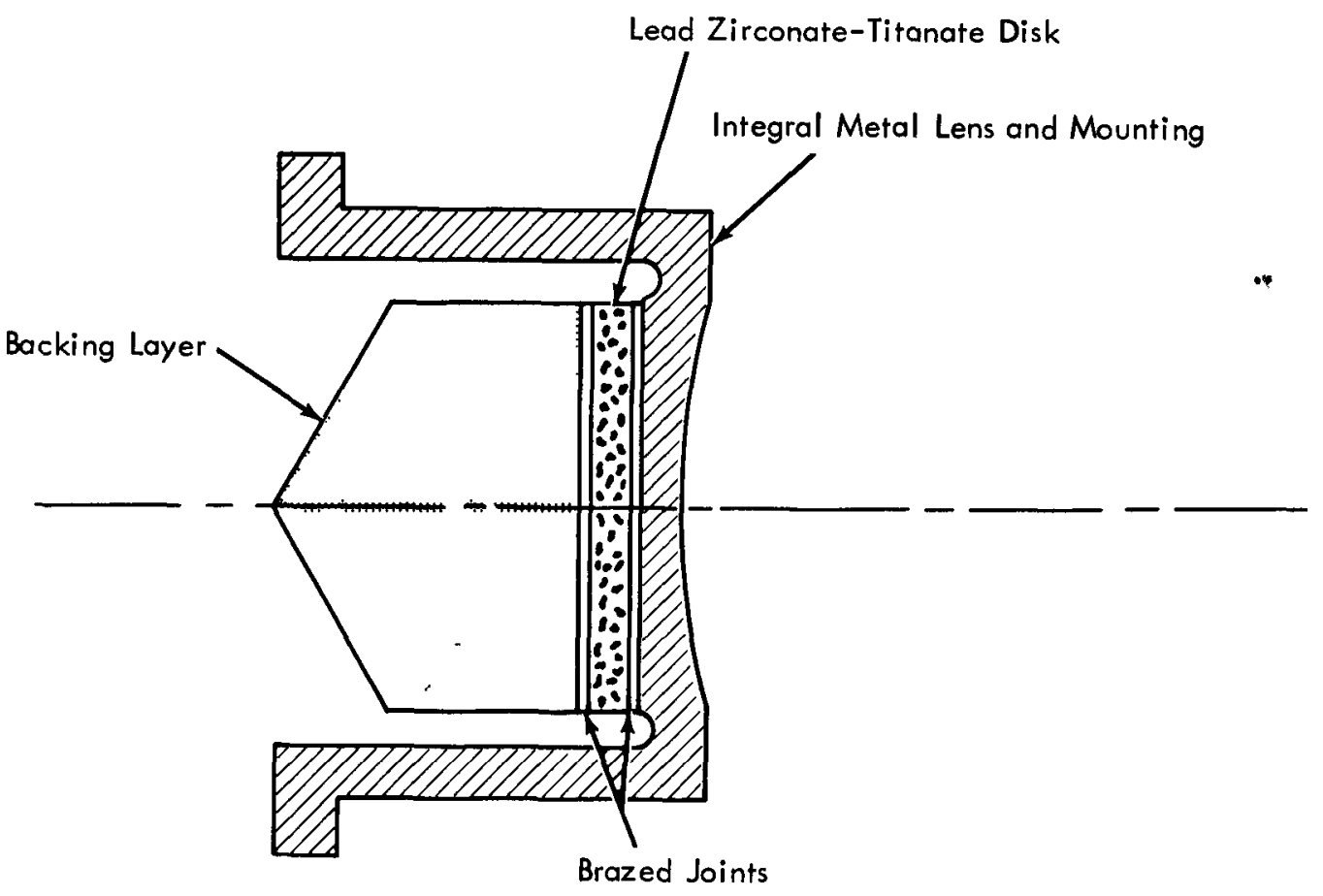

FIG.1 LENS, PIEZOELECTRIC DISK AND BACKING LAYER ASSEMBLY 
The heating of the test assemblies to permit diffusion bonding and brazing was performed in a vacuum muffle at a vacuum of more than 10 microns to minimize oxidation, gas absorption, and bubble entrapment.

Indium was chosen for the bonding (brazing) material. Its selection was based upon its excellent wettability for the ceramic, low fusion temperature, and capability to form alloy phases with other metals (e.g., silver, copper, and nickel) having melting points higher than its own. This bonding material was applied to the Monel lenses by plating from a cyanide salt plating solution for subsequent diffusion and alloying with the base metal during vacuum heating. To prevent possible permanent damage to the piezoelectric properties of the ceramic disk, the diffusion and brazing temperatures were limited to $800 \mathrm{~F}$ maximum. Indium-rich bonding alloys of silver, silver-copper, lead, tin, and copper were also made and applied to the ceramic disk and the Monel lenses by hot tinning methods, using a soldering iron to locally restrict the tinning. A small crucible made from hot,pressed boron nitride was used to prepare the various indium alloys because of its resistance to wetting by molten metals.

Three tests were conducted and preparations for a fourth were concluded before the program was terminated. The experiments are discussed below.

\section{Test I}

A 0.0002 -inch layer of indium was plated on the lapped face of a Monel lens, and a ceramic disk was cleaned with detergent and alcohol. The ceramic disk was placed in intimate contact with the indium-plated face under 1 psi pressure, and the whole assembly was then heated and cooled in a vacuum as follows:

$340 F-350 F$ for 8 hours

raised from $350 \mathrm{~F}$ to $600 \mathrm{~F}$ in 4 hours

$600 \mathrm{~F}-610 \mathrm{~F}$ for 10 hours

cooled from $600 \mathrm{~F}$ to room temperature in 10 hours.

The indium did not wet the silver coating (which was approximately $8 \times 10^{-6}$ inch thick) or the disk but did alloy and diffuse into the Monel lens.

\section{Test II}

An alloy of $25 \%$ indium $-75 \%$ lead was prepared and a ceramic disk and a Monel lens were tinned using a soldering iron to apply the brazing alloy. The indium-lead alloy wetted the ceramic disk quite well and produced a thin adherent braze layer when wiped lightly while molten to remove 
excess metal. The tinned transducer disk and the Monel lens were assembled as in the first test and then heated and cooled in a vacuum as follows:

\author{
$340 F-350 F$ for 2 hours \\ raised from $350 \mathrm{~F}$ to $600 \mathrm{~F}$ in 4 hours \\ $600 \mathrm{~F}-610 \mathrm{~F}$ for 10 hours \\ cooled from $600 \mathrm{~F}$ to room temperature in 10 hours.
}

The lens and the disk held together, but only a poor bond was produced; the lens and the disk were easily separated with a razor blade. Patches of braze-free areas showed on the disk, indicating poor adhesion to the ceramic material.

\title{
3. Test III
}

An alloy of $90 \%$ indium-9\% silver $-1 \%$ copper was prepared and formed into a wire and a small disk approximately 0.005 -inch thick. One side of a transducer disk and a 1-1/8-inch circular area on a Monel lens were tinned with this alloy; excess brazing metal was removed by lightly brushing while molten. The lens and the transducer disk were assembled as in previous tests but with the 0.005 -inch-thick braze alloy disk sandwiched between the tinned surfaces of the lens and the transducer disk. The assembly was then heated for 2 hours at $650 \mathrm{~F}$ in vacuum.

A small fillet formed around the periphery of the transducer disk with a few spots where the fillet had discontinuities in it. Pressing a razor blade edge against the fillet caused the transducer disk to separate from the Monel lens. Approximately 20\% of the disk area showed evidence of the braze filler metal not having coalesced. This was probably due to air entrapment or lack of braze metal flow.

\section{Test IV}

A $90 \%$ indium-10\% copper alloy was prepared and formed into wire and a 0.005 -inch-thick strip. However, the program was terminated before this bonding experiment could be conducted.

\section{Conclusions}

It is evident that since it is possible to produce a coating of indiumbase brazing alloy on the ceramic transducer disk by molten tinning techniques, it should be possible to bond the tinned ceramic to suitable metallic components. However, since it is difficult to establish even a partial intimate contact between the flat and smooth faces of a ceramic disk and a metallic component, a liquid phase is required to fill the depressions between the 
surface asperities during the bonding operation. The $8 \times 10^{-6}$ inch silver coating appears to completely dissolve by the alloy; therefore, it would seem advantageous to have this coating of considerably greater thickness, possibly as thick as $8 \times 10^{-3}$ inch. Also, it would be advantageous to have the coating made of such metals as nickel or cobalt which could be deposited on the ceramic by cathodic sputtering or chemical vapor plating methods. The thicker coating on the ceramic would provide more metal for obtaining smooth and flat faces and would provide more metal to alloy with the brazing metal, resulting in a higher melting alloy than the brazing metal after diffusion alloying during the bonding cycle. 
๑.

๑

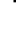




\section{ACOUSTIC ATtENUATION AS A FUNCTION OF IMPURITIES IN SODIUM}

One phase of the acoustic studies for FY-1968 was to determine the effect of impurities in sodium upon acoustic attenuation. This was to be accomplished by installing an ultrasonic transducer in the sodium technology loop and observing acoustic signals when various impurities of known quantities were injected into the flowing sodium.

An investigation was made to determine the extent of modifications required to install an ultrasonic transducer into the sodium technology loop. The results of the investigation indicated that the transducer should be installed in a bypass portion of the loop that was designed and fabricated to demonstrate the performance of the centrifuge. The installation of the transduce $r$ in this location would permit ready access to the unit without loop shutdown and would require only minor modifications to the existing loop. A sketch of the proposed location is shown in Figure 2. 


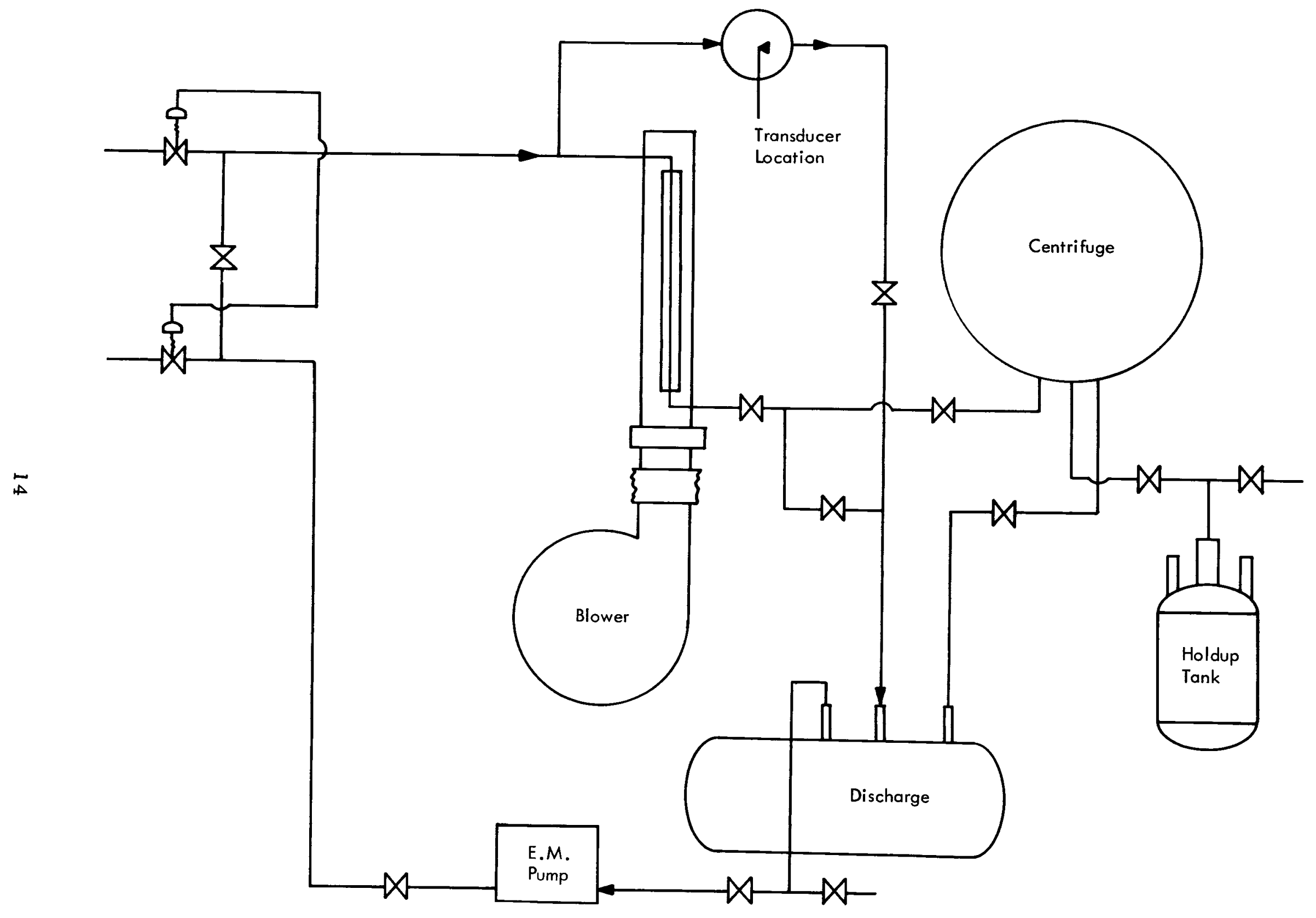

FIG.2 DIAGRAM OF CENTRIFUGE LOOP 


\section{DISTRIBUTION LIST}

USAEC - Chicago Operations Office

Director, Contracts Division (2)

$G \mathrm{H}$ Lee

USAEC - Washington, RDT

Director

Asst. Director, Program Management

Asst. Director, Reactor Engineering

Asst. Director, Reactor Technology

Asst. Director, Plant Engineering

Asst. Director, Nuclear Safety

Project Manager, LMEC

Project Manager, FFTF

Program Manager, LMFBR

Liquid Metal Projects Branch

Chem \& Chem Separations Branch

Reactor Physics Branch

Fuels and Materials Branch

Applications and Facilities Branch

Components Branch

Instrumentation and Control Branch

Systems Engineering Branch

Core Design Branch

Fuel Handling Branch

Special Technology Branch

Reactor Vessels Branch

USAEC-RDT Site Representatives

Site Representative, APDA

Senior Site Representative, ANL

Senior Site Representative, AI

Acting Senior Site Representative, IdOO

USAEC-DTIE

R. L Shannon (3)

USAEC - New York Operations Office

$\mathrm{J}$ Dissler

USAEC - San Francisco Operations Office J. Holliday

Director, LMFBR Program Office, ANL

A. Amorus 1

Director, LMEC, AI

R. W. Dickinson

Aerojet - General Corporation

H. Derow

\begin{tabular}{l} 
Argonne National Laboratory \\
\hline R. Bane \\
L. W. Fromm \\
S. Greenberg \\
L. J. Koch \\
S. Lawroski \\
M. Novick \\
F Smith
\end{tabular}

$\frac{\text { Atomics International }}{\mathrm{R} \text { Balent (2) }}$

Babcock \& Wilcox Company

(Box 1260, Lynchburg, Va 24505)

$\mathrm{M}$ W. Croft

Babcock \& Wilcox Company

(Barberton, Ohio)

P B Probert

Baldwın-Lima-Hamılton Corp.

(Industrial Equipment Div., Eddystone, $\mathrm{Pa}$ )

J. G. Gaydos

R. A. Trdball

Brookhaven National Laboratory

O. E. Dwyer

D Gurinsky (2)

$\mathrm{K}$ Hoffman

C. Klamut

L. Newman

A Romano

Combustion Engineering, Inc

(Box 500, Windsor, Conn)

$W P$ Staker

W. H. Zinn

General Electric Company

(175 Curtner, San Jose, Calıf 93125)

$K$ P Cohen (3)

General Electric Company

(310 DeGuigne, Sunnyvale, Calif 94086)

A Gibson

Gulf General Atomic, Div. of Gulf Oll Co. (San Diego, Calıfornia)

P. Fortescue

M. W Kellogg Company

(711 Third, New York, New York)

E. W. Jesser

Lew1s Flight Prop. Laboratory, NASA

(21000 Brookpark, Cleveland, Ohıo)

C. A. Barrett

Los Alamos Scientific Laboratory
D. B Hall (2)
G. Waterbury
W. R Wykoff

MSA Research Corporation

(Callery, Pa 14024)

C. H. Staub 
Nuclear Materials \& Equipment Corp. (Apollo, Pennsylvania)

Z. M. Shapiro

Oak Ridge National Laboratory (Box X, Oak Ridge, Tennessee)

F. L. Culler (2)

J. H. Devan

D. Gardiner

J. White

Oak Ridge National Laboratory

(Box Y, Oak Ridge, Tennessee)

R. E. MacPherson, Jr.

Pacific Northwest Laboratory, BMI E. Astley (5)

Power Reactor Development Company (1911 First, Detroit, Michigan 48226) A. S. Griswold

Southwest Atomic Energy Associates (Box 1106, Shreveport, La 71102)

J. R. Welsh

United Nuclear Corporation (Box 1583, New Haven, Conn)

A. Strasser (2)

Westinghouse Electric Corporation (Box 158, Madison, $\mathrm{Pa}$ 15663)

J. C. R. Kelly, Jr. (2)

Westinghouse Electric Corporation

(Box 158, Madison, Pa 15663)

C. A. Anderson

USAEC-UKAEA Exchange UKAEA

Reactor Group Headquarters

Risley, Warrington, Lancashire

England

J. Stephens on (12)

\section{USAEC-EURATOM Exchange}

\section{EURATOM}

53, Rue Belliard

Brussels 4, Belgium
A. deStordeur (10)

\section{CNEN}

Via Mazzini 2

Bologna, Italy

F. Pierantoni (4)
CEN Saclay

Boite Postale 2

Gif-Sur-Yvette (Set 0) France

G. Vendryes $(10)$

Kernfors chungszentrum Karls ruhe 7500 Karls ruhe, Germany

W. Haefele (10) 